\title{
Determination of Flavonoid, Tannin and Vitamin C Content from Methanol Extract Wrapping Stone Banana (Musa brachycarpa), Ketip Banana (Musa Paradisiaca Forma Typiaca) and Kepok Banana (Musa acuminata)
}

\author{
Ni Putu Adriani Astiti* and Dwi Ariani Yulihastuti \\ Biology department, Faculty of Matematic and Natural Science Udayana University, Bali \\ *Corresponding author: adriani@unud.ac.id
}

\begin{abstract}
Research has been done to investigate the levels of flavanoid, tannin, and vitamin $\mathrm{C}$ of methanol extract of Stone banana (Musa brachycarpa), Ketip banana (Musa paradisiaca forma typiaca), and Kepok banana (Musa acuminata). Jukut Ares is a Balinese traditional cuisine frequently served in any events of celebrations. The use of young stems of such banana varieties as the main raw materials in the process of making jukut ares has not been scientifically elucidated. Antioxidants are compounds with ability to inhibit oxidation-related reactions due to free radicals that cause disturbance of saturated fatty acids of cell membrane, blood vessels, DNA, as well as adipose tissues which lead to occurrence of various diseases. Plants components will have antioxidant activities if they contain compounds (phenol and flavanoid) with ability to scavenge free radicals. Tannin is a water based phenolic compound and vitamin $\mathrm{C}$ is also a water based vitamin that play important roles in preventing us from various diseases. Extraction was conducted by applying maceration method and to investigate the levels of flavanoid, spectrophotometric UV vis with aluminum chloride ( $\mathrm{AlCl}$ ) was applied. The level of vitamin $\mathrm{C}$ of the materials was conducted by Iodine titration method, while the level of tannin was determind by applying spectrophotometri. The results showed that methanol extract of Ketip banana stem contained the highest level of flavanoid with a quantity of $53.13 \mathrm{mg} / 100 \mathrm{gr}$ QE, and this was followed by stone banana (36.28) and kepok banana (32.07) The highest vitamin C level was indicated in the extract of ketip banana $(418.32 \mathrm{mg} / 100 \mathrm{gr})$, which is followed by kapok banana and stone banana. In the calculation of tannin content, pisang ketip showed the highest level, while pisang batu contained the lowest level of tannin.
\end{abstract}

\section{Keywords: Flavonoid, Vitamin C, tannin, stem of banana}

\section{INTRODUCTION}

Utilization of banana stem as one of the vegetables for the people of Bali to make "Jukut Ares" as one of the favorite vegetables in Bali. Not much scientific information is found from the banana stems. Many types of bananas exist in Bali, but has not known yet to the type of banana that is effective as an antioxidant. Antioxidants are actually defined as inhibitors that act to inhibit oxidation by reacting with reactive free radicals to form a relatively stable unreactive free radical. But regarding free radicals associated with disease, it would be more appropriate if antioxidants are defined as compounds that protect cells from the harmful effects of reactive oxygen free radicals [1].

It needs to explore the active ecological compounds of each type of banana and its potential. Goroho banana (Musa acuminate) is a typiaca plant of North Sulawesi region that has many uses and has a diverse chemical content and good for health. One of them Antioxidants that work to prevent the occurrence of damage to body cells, such as damage the pancreatic $\beta$ cells. Treatment and health care are expensive, especially in patients with clinical complications, which encourages some people to look for safer alternatives, provide relatively lower side effects, and are easy to obtain by utilizing traditional medicinal plants.
Tannin is an active compound that acts as an antidiarrheal. Tannins are composed of a very complex mixture of polyphenolic compounds and are usually associated with low carbohydrates. The tannins are secondary plant metabolites that are astrigen with a distinctive flavor.

In Bali many various types of bananas be used as Ares jukut, but has not been much is known of the efficacy of each banana. The use of Banana stone, banana ketip and banana kepok in this research is very limited utilization the fruit of this type of banana as a fruit to be consumed directly as a dessert. This could be due the banana is a fruit that contains many seeds so that making it difficult to consume, although it is tastes sweet tastes.

Banana fruit poppers can not be eaten directly, only used for materials for kolak or other food, because to hard in texture during direct comsumpition beside and it also less Tasty. Mean while kepok banana widely used for "kolak" or as bird food therefore diversification of banana crops has various purposes, especially concerning with health should it be explored the benefits, in order to maintain the biodiversity of banana crops.

The aims of this research is to investigate the content of flavonoids, tannin and vitamin $\mathrm{C}$ from banana stone (Musa brachycarpa), banana Ketip (Musa paradisiaca forma typical) and banana kepok (Musa acuminata) as antioxidant thus it is contested to treat degenerative diseases. 


\section{RESEARCH METHODS}

\section{Extraction Method}

The stem of banana stalk used in this study is the bark part of a young banana plant with a height of more or lees 1 meter. Banana stems and then washed with water flowing and cut into small pieces, then dried with freeze drying technique. Next step extraction method use in this experiment is maseration, which is soaking dried banana stem with $70 \%$ metanol of $5 \mathrm{~cm}$ methanol $70 \%$ above the surface of the sample. Immersion is carried out $3 \times 24$ hours under occasionally stirring every day, screening and the result is evaporated with vaccum rotary evaporator with $40-50^{\circ} \mathrm{C}$ a heating temperature until extract is obtained.

\section{Flavonoid Test}

Each banana stem thick extract, taken as much as 0.1 gram is than dissolved with $10 \mathrm{~mL}$ methanol, each divided into 4 test tubes. The first reaction tube as a control, second, third and fourth test tubes were added concentrated $\mathrm{H}_{2} \mathrm{SO} 4, \mathrm{NaOH}$, and $\mathrm{Mg}-\mathrm{HCl}$ respectively. The colour change of each tube is compared to the control tube, and if any color change happened indicates that the positive contains of flavonoids [2]. Preparation of Standard Solution Quercetin was weighed as much as $10 \mathrm{mg}$, inserted in $50 \mathrm{~mL}$ cup glass and dissolved with $25 \mathrm{~mL}$ of methanol, then stirred until homogeneous state. After that the solution was transferred into a $100 \mathrm{~mL}$ powdered flask and added methanol to the exe line, then cornered to homogeneous. The standard raw solution was diluted to obtain a working standard solution of $0.1 \mathrm{ppm}, 0.5 \mathrm{ppm}, 1$ ppm, $1.5 \mathrm{ppm}, 2 \mathrm{ppm}$ and $2.5 \mathrm{ppm}$. Flavonoid content analysis to determine flavonoid levels by UV Vis spectrophotometry using aluminum chloride solution $\left(\mathrm{AlCl}_{3}\right)$, wavelength optimization was performed to determine the maximum wavelength to be used in the measurement using standard solution. A total of $1.5 \mathrm{~mL}$ of extract solution from each sample was taken at a concentration of $0.5 \%$ and added with $1.5 \mathrm{~mL} \mathrm{AlCl} 31 \%$. After 10 minutes absorbance is measured at maximum wavelength. The absorbance readings were performed using a calibration curve. The results were expressed as the mean of three measurements and the flavonoid content was expressed with equivalence of standard flavonoid solution using quercetin standard comparator. The absorption was measured by a spectrophotometer at a wavelength of 300$400 \mathrm{~nm}$ [3].

\section{Determination of Vitamin C}

Determination of vitamin $\mathrm{C}$ levels in this study using Iodium Titration method. Titrations using Iodine as oxidizing agents that oxidize vitamin $\mathrm{C}$ and use starch as an indicator. Methods of measurement of vitamin $\mathrm{C}$ levels were performed using redox iodometric titration. The trick is to add tapioka powder (indicator) solution to the sample solution, then titrated with iodine solution $\left(\mathrm{I}_{2}\right)$. Titration process ends when the color of the solution turns blue.

\section{RESULTS AND DISCUSSION}

Results

The results of Flavonoid content analysis on the three types of bananas, ketip banana showed the highest levels of flavonoids $(53.13 \mathrm{mg} / 100 \mathrm{~g}$ QE), followed by banana stone $(36.28 \mathrm{mg} / 100 \mathrm{~g}$ QE). The lowest flavonoid level is shown by banana stalk $32.07 \mathrm{mg} / 100 \mathrm{~g} \mathrm{QE}$ ). Result of flavonoid measurement are shown in the Figure 1.

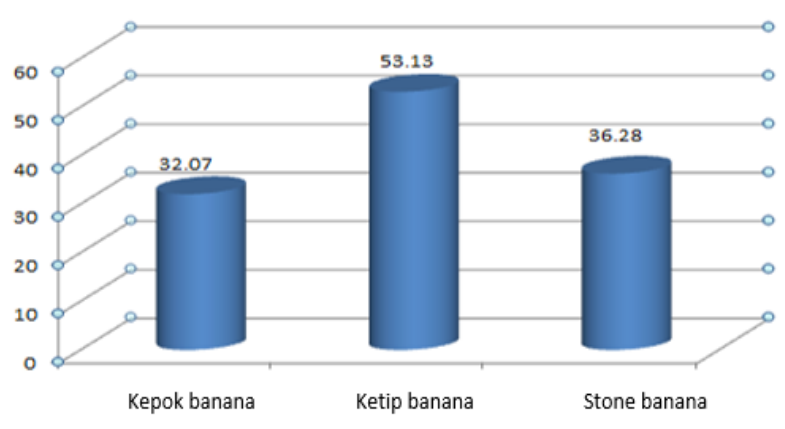

Fig. 1. Flavonoid content of metanol extract of banana stem bark of kepok, ketip and stone banana.

In analyzing the levels of flavonoids required a standard series of quercetin compounds with variations of $0.0 \mathrm{ppm}, 2.0 \mathrm{ppm} 4.0 \mathrm{ppm}, 8.0 \mathrm{ppm}, 12.0 \mathrm{ppm}$ and 16.0 ppm. and $20 \mathrm{ppm}$. Then the absorbance was measured at a maximum wavelength of $374 \mathrm{~nm}$ to obtain the standard quattin compound calibration curve. Data on the determination of the absorbance of standard quersetin solutions is presented in Table 1. Determination of the Absorbance of the Quirtin Standard Solution The calibration curve is used to achieve the measurement traceability, determining the conventional truth of the value indicated by the instrument and the sample being measured. The calibration curve is obtained by making standard quersetin solution, the purpose of making standard solution is to measure the level of data accuracy.

TABLE 1.

DETERMINATION OF SOLVENT ABSORBANCE STANDARD QUERSETIN

\begin{tabular}{ccc}
\hline No & Concentration & Absorbance \\
\hline 1 & 0.0 & 0.000 \\
2 & 2.0 & 0.120 \\
3 & 4.0 & 0.231 \\
4 & 8.0 & 0.440 \\
5 & 12.0 & 0.737 \\
6 & 16.0 & 0.954 \\
7 & 20.0 & 1.217 \\
\hline
\end{tabular}

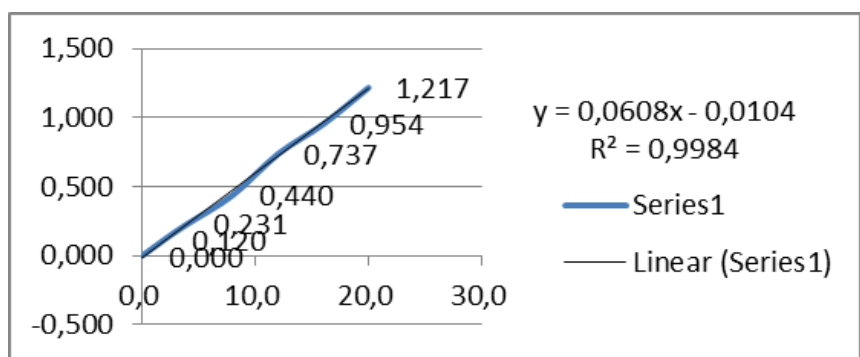

Fig. 2. The calibration curve of quersetin standard solution

Based on the calibration curve in Figure 2, linear regression equation of $y=0,0608 x+0,0104$ with correlation coefficient $(\mathrm{r} 2)$ is 0.9984 indicating that the 
concentration is able Explained the absorbance diversity of $99.84 \%$. The result of measurement of absorbance of standard solution At various concentrations obtained a linear relationship between the absorbance with the concentration shown with the measurement of linearity of 0.9984. The magnitude of this linearity is approaching one so that it can be said that absorbance is a function whose magnitude is directly proportional to concentration and follows a linear regression equation.

From the results of vitamin $\mathrm{C}$ content analysis obtained the highest levels of vitamin $\mathrm{C}$ found in banana staplast stem ripe extract of $418.32 \mathrm{mg} / 100 \mathrm{~g}$ extract. The lowest levels of vitamin $\mathrm{C}$ were found in banana stem bark extract. It was $367.98 \mathrm{mg} / 100 \mathrm{~g}$ extract. More data is shown in Figure 3.

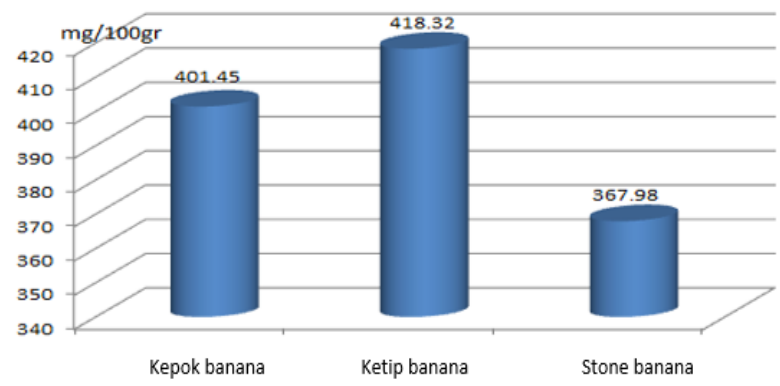

Fig. 3. Levels of Vitamin C content of metanol stem extract of kepok, ketip and stone bananas.

Result of calculation of tannin content showed that most tannin content found in banana Ketip almost equal to kepok banana which showed lower tannin content. While the lowest content tannins are found in banana stalk bark extracts.

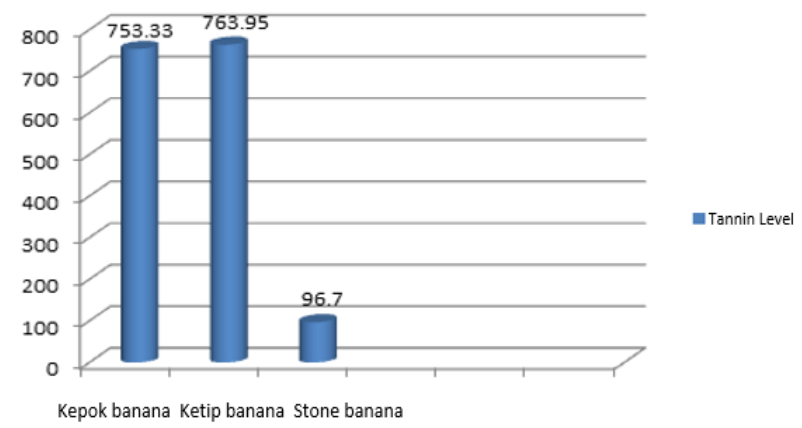

Fig. 4. Tanin content of metanol extract of stem midrib kapok banana, ketip banana and stone bananas.

\section{Discussion}

The highest content of flavonoids and vitamin $\mathrm{C}$ on stem extract of the three types of bananas is found in ketip banana compared to kepok banana and stone stone. Several studies have been conducted to look at the relationship of flavonoid content with antioxidant activity. The fact is supported by Kao [4] showed that the phenol and flavonoid content in blackberries is directly proportional to antioxidant activity and flavonoids are one of the largest natural phenolic-type antioxidant compounds present in all plants, so from the data analysis indicated ketip banana has the potential to be used as a source of antioxidants.

It is also meant that there is a relationship between total phenol content, total flavonoids, and antioxidant activity in metanol extracts. Ketip banana. Ketip banana also proved to contain the highest vitamin $\mathrm{C}$ among the three types of bananas studied. As an antioxidant, vitamin $\mathrm{C}$ is able to neutralize free radicals throughout the body. From this result it could be summerised that vitamin $\mathrm{C}$ content banana stem is very potential to be used as a source of antioxidants that possibly new fraksed free radicals, in treating degenerative diseases.

From tannin content it also be meaned that banana stem has potencial used as antidiarrhoea, because tannin compound act as astringent, that is covering intestinal mucosa, especially colon and collapse intestinal mucous membrane, as absorber poison and coagulate protein. Overall, it could be said that, tannin compounds could stop diarrhea. Tanin also has potential used as an antiseptic, and antioxidant,

\section{CONCLUSION}

Based on the results of a series of analysis it is concluded that the content of flavonoid tannin and vitamin $\mathrm{C}$ most contained in the extract of stem banana stems Ketip, so banana ketip potentially can be used to treat degenerative diseases because it contains antioxidants that can counteract free radicals.

\section{ACKNOWLEDGMENT}

I would like to express my gratitude to Udayana University for funding this research with contract number 641-71/UN14.2/PNL.01.03.00/2016.

\section{REFERENCES}

[1] Sofian, A. 2005. Potensi Produk Fermentasi Kacang Kedelai Sebagai Pengendali Kadar Kolesterol Darah. Skripsi. Program Studi Biokimia, Departemen Kimia, Fakultas Matematika dan Ilmu Pengetahuan Alam, Institut Pertanian Bogor, Bogor.

[2] Harborne, J.B. 1987. Metode Fitokimia. Bandung: Penerbit ITB.

[3] Chang, C. M., When, H. J., 2002. Estimation of Total Flavonoid Content in Propolis by Two Complentary Spektrofotometer UVVis Methods, J. Food Drugs, Annal. England.

[4] Kao M.W.S., Woods F.M., Dozier W.A., Jr., Ebel R.C., Nesbitt M., Jee J., Fields D.2008. Phenolic content and antioxidant capacities of Alabama-grown thornless blackberries. Int. J. Fruit Sci. 7:33-46 